Attanasio, O. y M. Browning (1995), "Consumption over the Life Cycle and over the Business Cycle", The American Economic Review, núm. 85, pp. 1118-1137.

Ayala, Ulpiano (1997), “The Impact of Mexican Pension Reform on Savings", Mexico, Mobilizing Savings for Growth, Banco Mundial, abril (mimeografiado).

Browning, Deaton e Irish (1985), "A Profitable Approach to Labor Supply and Commodity Demand over the Life Cycle", Econométrica, núm. 53, pp. 503-544.

Feldstein, Martin (1974), "Social Security, Induced Retirement and Aggregate Accumulation", Journal of Political Economy, núm. 90, pp. 630-642.

Magnussen, Knut (1994), “Old Age and Pension Saving”, Social and Economic Studies, núm. 87, Statistics Norway.

Modigliani, Franco (1975), "The Life-Cycle Hypothesis of Saving Twenty Years Later", en Michael Parkin (ed.), Contemporary Issues in Economics, Manchester University Press.

Paxson, C. (1996), "Saving and Growth: Evidence from Micro Data", European Economic Review, núm. 40, pp. 255-288.

Sales C., F. Solís y A. Villagómez (1998), "Pension System Reform: The Mexican Case", en Martin Feldstein (ed.), Privatizing Social Security, NBER, University of Chicago Press.

Solís Soberón, F. y A. Villagómez (1997), Las pensiones en México, Documento de Trabajo 87, México, División de Economía, CIDE.

Schmidt Hebbel, Klaus (1997), "Does Pension Reform Really Spur Saving and Growth?”, noviembre (mimeografiado).

\section{The Long-run Sustainability of Fiscal Policy in Mexico: A Generational Accounting Approach*}

\author{
Carlos Sales Sarrapy and Luis Videgaray Caso**
}

\begin{abstract}
This paper applies for the first time the generational accounting methodology to appraise the sustainability of current fiscal policies in Mexico. Generational accounting measures the consequences for future generations of current fiscal policies. Our main finding is that there is no evidence of a fiscal sustainability problem of the sort found for other countries in similar studies. The result is mainly due to favorable demographic dynamics over the coming decades and is robust to several alternative data assumptions. We conclude there is no evident need to raise overall taxes and that tax reform should focus on efficiency issues.

Resumen: Este artículo aplica, por primera vez, la metodología de Cuentas Generacionales para evaluar la sustentabilidad de la política fiscal en México. La metodología estima las consecuencias de las políticas fiscales actuales sobre las generaciones futuras. El principal resultado es que, a diferencia de lo encontrado para otros países, en México no existe evidencia de que la política fiscal actual sea insostenible básicamente a diversos supuestos a favorables. Se concluye que no existe necesid, y a factores demográficos tributaria, por lo que una reforma fiscal debe enfocarse a mejorar la tributaria, por lo que
eficiencia del sistema.
\end{abstract}

\footnotetext{
* Paper prepared for the Conference on Perspectives of Saving in Mexico, October 1998, organized by the CIDE and CONSAR.
}

** Protego and ITAM. We thank Augusto Arellano for outstanding reseach assigtance Larry Kotlikoff, Alan Auberbach and Philip Oreopoulos for outstanding research assistance Fernando Aportela and Juan Manuel Valle for providing data; and Agustín Carsteir software; Sobarzo and participants at the Conference on Perspectives of Saving in Mexico for comoracio and suggestions. The opinions presented in this paper are necessarily represent the view of the institutions to which they are of the author 


\section{Introduction}

The public sector's balance has been a central issue in macroeconomic 1 policy discussions in Mexico. However, the debate is usually focused on the short-run macroeconomic implications of the public sector's deficit (or surplus) without addressing its sustainability over the longterm or its implications for different generations. This paper attempts to analyze the long-term impact of fiscal policy in Mexico by evaluating the intertemporal distribution of the fiscal burden among present and future generations.

We use the methodology of generational accounting developed by Auerbach, Gokhale and Kotlikoff in 1991.' In essence, generational accounts indicate, in present value, what the typical member of each generation can expect to pay, now and in the future, in net taxes (taxes paid minus transfers received from the government). The analysis presents both what existing and future generations will pay, given current fiscal policy and the government's intertemporal constraint. Sustainability of current fiscal policy can then be assessed by analyzing what future generations will have to pay compared to existing ones in order to satisfy the government's constraint. If the burden for future generations is significantly larger than for existing ones, there would be reason to worry about the long-term sustainability of current fiscal policy.

A seminal contribution to public economics, generational accounting has spread rapidly. The methodology was first applied to the United States, ${ }^{2}$ and has then emerged as a solid tool of fiscal analysis and planning, which has already been applied to at least 23 nations around the world. ${ }^{3}$ Moreover, generational accounting is being used by the governments of the United States, Japan, Italy and Norway.

This paper applies, for the first time, generational accounting to assess overall fiscal policy sustainability in Mexico. ${ }^{4}$ The paper focuses mainly on evaluating the generational implications of current fiscal policy in Mexico. Another important application, which is left for

1 Their seminal paper was A. J. Auerbach, J. Gokhale and L. J. Kotlikoff (1991). The methodology is also presented in many other papers such as A. J. Auerbach, J. Gokhale and L. J. Kotlikoff (1994).

J. Gokhale, B. R. Page and J. R. Sturrock (1998).

3 A. Auerbach, L. J. Kotlikoff and W. Leibfritz, editors (forticoming 1999), and L. J. Kotlikoff and W. Leibfritz (1998).

4 Serrano (1998) performs a generational accounting analysis of the Mexican social security system, but does not evaluate the sustainability of overall fiscal policy. future research, would have been the analysis of intertemporal effects of certain policy reforms. We basically apply the methodology as it has been used for other countries, taking into account certain specific issues that are particularly important for the Mexican case, such as the demographic transition, pension and health reforms, oil revenues and the fiscal cost of several financial rescue packages that have been recently implemented by the government. Where necessary, we made some assumptions about these and other variables which are explicitly presented in the paper and, in most cases, subjected to sensitivity analysis. However we recognize that there can be other reasonable assumptions, different from the ones we made. In this sense our results should not be taken as definitive, but rather as an attempt to promote a forward-looking analytical discussion about Mexican public finances.

Our main conclusion is that there is no intergenerational imbalance of the sort found for other countries. In fact, our base case results show that the accounts of future generations are 11 percent smaller than the accounts of newborns, meaning that there is no evidence of fiscal sustainability problem. We also show that this conclusion is mainly due to very favorable demographics. Without the expected population dynamics, a major imbalance would arise. The results also show that oil revenue plays a key role in balancing generational accounts. Our results are sensitive to several alternative data assumptions, but the basic conclusion is that there is no evidence of a significant imbalance.

Our results also point towards some policy implications. During the next few decades Mexico will undergo a highly favorable demographic transition. The non-existence of a large imbalance between existing and future generations in most scenarios implies that there is no obvious need to substantially increase the overall level of taxation in the Mexican economy. The main focus of tax policy reform should be mostly microeconomic, with the aim of designing a more efficient tax structure. The demographic transition will also open a window of opportunity to carry out structural reforms that imply inter-generational transfers. Aside from pension reform for workers in the private sector which was timely implemented in 1995, other important sectors that need to be reformed include health, housing and public sector workers' pensions.

The paper is divided into five sections. The first one presents a brief overview of generational accounts methodology. The second 
section presents the data and the assumptions that we used in applying the methodology to the Mexican case. In the third section we present our base-case results and show several sensitivity analyses, and in the fourth we look at the path of the government deficit. The paper ends by summarizing the results and by providing some ideas about policy implications and future research.

\section{The Generational Accounting Methodology}

Generational accounting is a meaningful method to appraise the intertemporal stance of fiscal policy. Generational accounts are a better tool than the current government deficit, which is based on the arbitrary labeling of items and has limited use in understanding the future evolution of public finances because fiscal policy is dynamic and cannot be described by a static indicator. In contrast, the generational accounting methodology is specifically designed to evaluate the consequences that current expenditure and revenue policies will have in the future.

The generational accounting methodology is based on recognizing that the government faces an intertemporal budget constraint. Although the government enjoys the ability to spend beyond its revenues at a given point in time (by increasing its debt), sooner or later either revenues will have to be increased or expenditures will have to be cut in order to comply with the intertemporal budget constraint. If current generations do not rectify an unsustainable path, future generations will be forced to bear the burden of adjustment. Generational accounts provide a way to measure such burden.

A generational account is defined as the present value of taxes paid minus transfer payments received (net taxes) that individuals of different anual cohorts (generations) pay on average over their remaining lifetimes. The account of an average individual of a generation born in the past is defined as follows:

$$
N_{t, k}=\sum_{s=t}^{k+D} \frac{\bar{T}_{s, k} P_{s, k}}{(1+r)^{s-t}}
$$

Where $N_{t, k}$ is the account in year $t$ (the base year) of a person born in year $k \cdot T_{s, k}$ stands for the projected average net payment to the government made in year $s$ by a member of the cohort born in year $k$, the term $P_{s, k}$ is the probability of survival by year $s$ of members of the cohort born in year $k, r$ is the discount rate and $D$ is the maximum length of life. The summation in the right-hand side of (1) is then the expected net present value of net tax payments to be paid by an individual over his or her remaining lifetime.

From expression (1) we can see that only for those born in the base year $t$ the generational account will reflect the complete lifecycle; for those born in the past the account reflects only the remaining lifetime. Therefore, the appropriate benchmark against which to compare the generational accounts of future generations (those not yet born) is the generational account of the newborns. If the accounts of future generations are larger than the account of the newborns, there is generational imbalance, in the sense that future generations will be forced to bear a larger net tax burden over their lifetimes than the currently living will. If, however, the accounts of future generations are smaller than the account of the newborns, there is a "negative" imbalance, meaning that future generations will be able to pay lower net taxes over their lifetimes.

In order to calculate the generational accounts of future generations, the methodology makes use of the intertemporal budget constraint of the government. The intertemporal constraint implies that the sum of future government spending has to be equal to the sum of all future net taxes (taxes minus transfers all in present value terms) plus current government net wealth. Once the generational accounts of those currently living are calculated and government spending is projected, the accounts of those born in the future can be computed as a growth-adjusted residual by assuming that future generations pay, in the form of net taxes, all the government bills left unpaid by existing generations. This assumption ensures that the difference between the accounts of the newborns and the accounts of future generations reflects the required adjustment needed to restore fiscal sustainability. ${ }^{5}$

The generational accounting methodology has been applied to a growing number of countries, showing how traditional indicators of fiscal policy soundness - such as the government deficit or the ratio of public debt to GDP - can be misleading, as they may have little or

${ }^{5}$ A detailed description of the methodology can be found in Auerbach, Gokhale and Kotlikoff (1991, 1992, 1994). 
no correlation to imbalances that may exist in net tax payments of different generations. The studies also show that many countries will leave a sizeable burden to future generations if current policies are not changed, although this conclusion is not universal. Kotlikoff and Leibfritz (1998) summarize the findings of 17 countries studies, of which 13 show generational imbalances. Five countries (Japan, Italy, Germany, Netherlands and Brazil) have extreme imbalances, one (Canada) appears to be essentially in balance, and three (New Zealand, Sweden and Thailand) show negative imbalances (a generational surplus). These differences in generational balances across countries arise basically from differences in expected population dynamics and in current fiscal policies. ${ }^{6}$

\section{Assumptions and Data for the Mexican Case}

The calculation of generational accounts for both living and future generations relies on several assumptions that have a critical impact on the results. The four main inputs are: 1) demographic projections (regarding both the overall growth rate and yearly age distributions); 2) the distribution across ages of each type of tax and transfer, for each projection year; 3) aggregate projections for each type of tax and transfer; 4) the labor productivity growth and discount rates. In this section we discuss each in turn.

\subsection{Population Projections}

Given the long-term nature of the generational accounting framework, it is natural that population projections have a major influence on the results. Demographic projections matter because the age distribution of the population affects the structure of public finances: a significant proportion of lifetime taxes is paid during working years, while many important transfers - such as pensions or health benefits for children and the elderly - are received during non-working years. Moreover, demographics also affect intergenerational balance because the rate of growth of population has an important effect in the rate of growth

${ }^{6}$ The 17 countries studies summarized in Kotlikoff and Leibfritz (1998) will be published in a forthcoming NBER volume. of the economy, which in turn affects the growth of public revenue and expenditure. Therefore, the expected evolution of total dependency ratios (the ratio of people in non-working ages to people in working ages) has great impact on the expected path of government finance. If the total dependency ratio is expected to increase over the coming decades (as in most developed countries), then demographics is a factor playing against generational balance. If the ratio is expected to decrease (as in Mexico and Thailand), demographics contributes to the sustainability of fiscal policy.

In this paper we use the demographic projections produced by the Consejo Nacional de Población (CONAPO), a Mexican government institution. The CONAPO projections, which run from the present to the year 2030 , indicate that Mexico will go through a very important demographic transition. First, the overall rate of growth of population will decrease from 3.4 percent in the period $1970-2000$, to 1.0 percent in the period 2000-2030. Second, the population is aging. While in 1990 the average age of Mexican men and women were 23 and 24 percent respectively, by the year 2030 it will be 36 and 38 percent. Third, dependency ratios will change dramatically. While the elderly dependency ratio (elderly to working age individuals) will increase from 6.4 percent in 1990 to 14.8 percent in 2030 - meaning that each working Mexican will have to support a growing number elderly people - the total dependency ratio will decrease from 71.6 percent in 1990 to 48.1 percent in 2030, due to the larger effect of having less children per working adult.

The projected evolution of the total dependency ratio indicates that although the population will age, this process is still in an early stage, therefore contributing to generational balance over the next three decades. This contrasts with the expected demographic dynamics of other nations, such as the U.S., which will face over the next decades a later stage of the aging process. Figure 1a shows the age distributions of Mexican population in the years 1997 and 2030 and Figure 1b shows the same distributions for U.S. population. By comparing the figures we observe that both distributions are moving in similar directions, but that the right-hand side tail is thicker for the U.S. in both 1997 and 2030. This is reflected in the total dependency ratio for the U.S., which will increase from 51.7 percent in 1997 to 68.0 percent in $2030 .{ }^{7}$ As opposed to the Mexican case, demographics play

${ }^{7}$ World Bank Projections 1994 
Figure 1a. Mexican Population (Age Distribution)

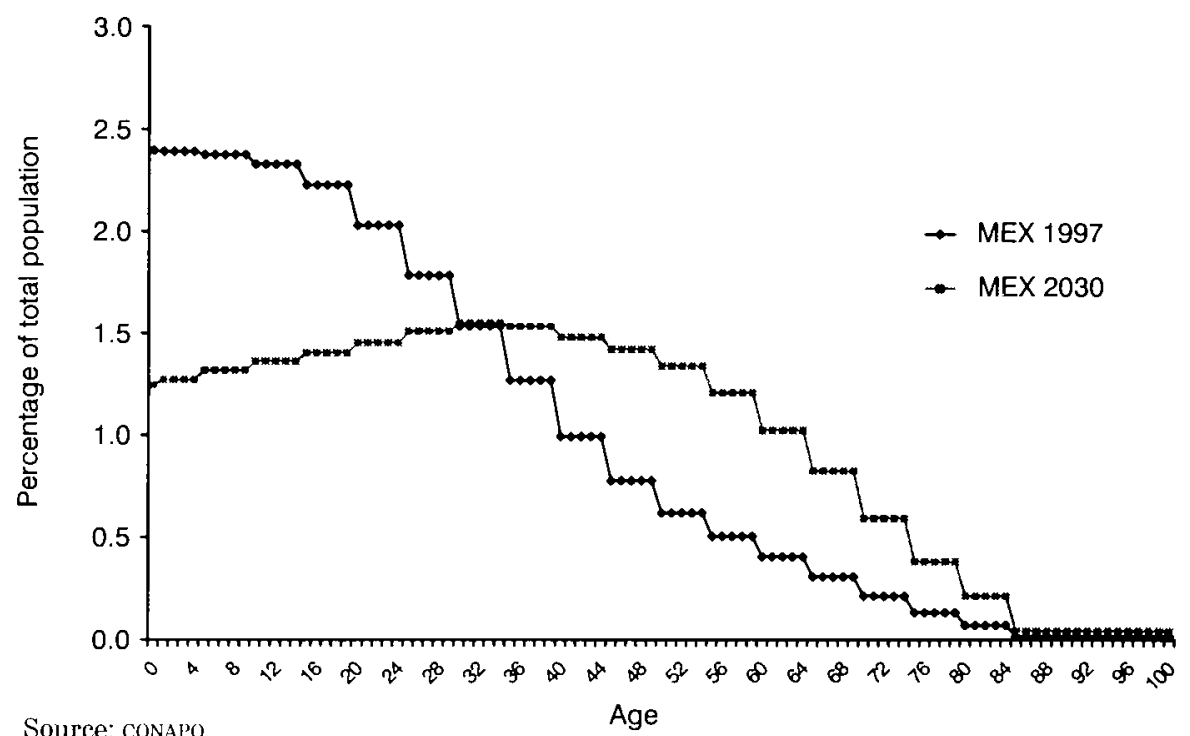

Source: CONAPO

Figure 1b. U.S. Population (Age Distribution)

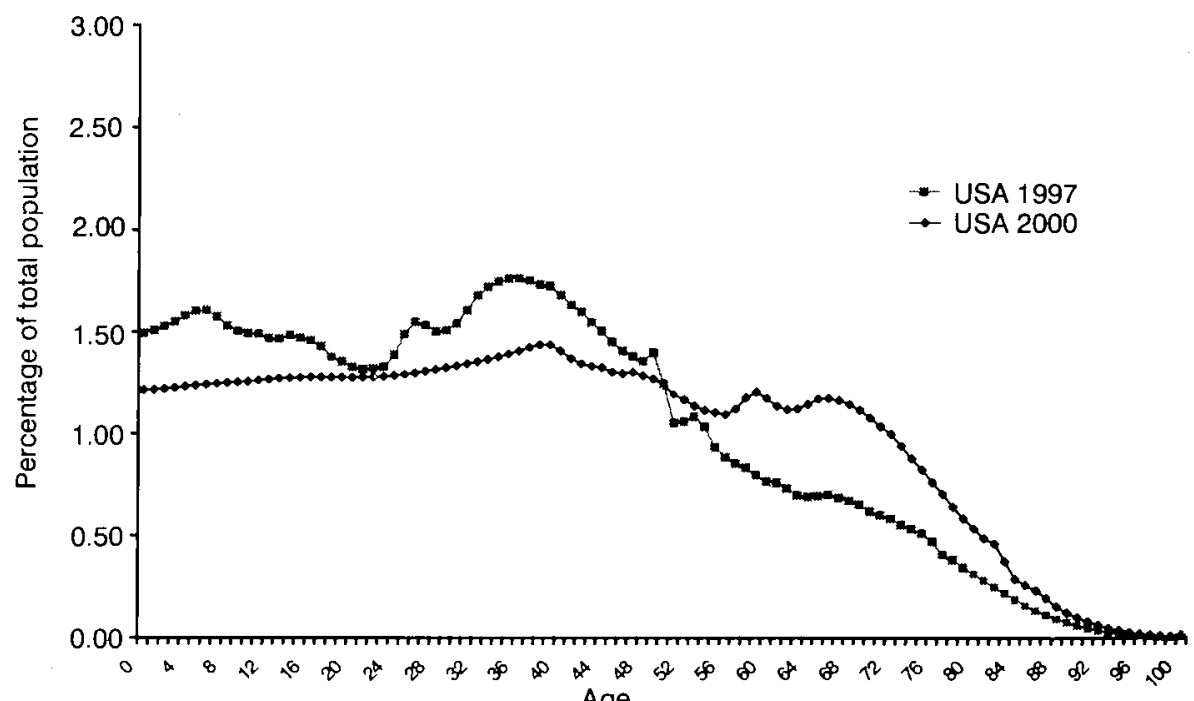

Source: Social Security Administration against generational balance in the U.S. and in many other (mostly developed) nations. Table 1 shows dependency ratios for 16 countries. For all except Mexico and Thailand the total dependency ratio will increase from 1990 to 2030, making generational balance harder to achieve.

A limitation of CONAPO projections is that they cover only the 1999-2030 period, which is not a long enough horizon for the generational accounting analysis. Most studies of this kind use projections that reach at least 100 years. In order to extend Conapo's projections we use two assumptions. First, we assume that the evolution of the age distribution of the Mexican population after the year 2030 will be similar to the evolution of such distribution for the U.S. in the coming decades. This assumption is based on the observation that the current distribution for the U.S. is close to the expected distribution

Table 1. Demographic Trends

\begin{tabular}{lccccc} 
& \multicolumn{2}{c}{ Elderly dep. ratio } & & \multicolumn{2}{c}{ Total dep. ratio } \\
\cline { 2 - 3 } \cline { 5 - 6 } \multicolumn{1}{c}{ Country } & 1990 & 2030 & & 1990 & 2030 \\
\hline Japan & 17.1 & 44.5 & & 43.5 & 70.5 \\
Italy & 21.6 & 48.3 & & 45.5 & 72.7 \\
Germany & 21.7 & 49.2 & & 45.3 & 75.1 \\
Netherlands & 19.1 & 45.1 & & 44.5 & 73.2 \\
Norway & 25.2 & 38.7 & & 54.4 & 68.3 \\
Portugal & 19.5 & 33.5 & & 50.7 & 59.8 \\
Belgium & 22.4 & 41.1 & & 49.2 & 68.9 \\
United States & 19.1 & 36.8 & & 51.7 & 68.0 \\
Denmark & 22.7 & 37.7 & & 47.9 & 67.0 \\
France & 20.8 & 39.1 & & 51.1 & 67.9 \\
Australia & 16.0 & 33.0 & & 48.9 & 62.6 \\
Canada & 16.7 & 39.1 & & 47.5 & 69.0 \\
New Zealand & 16.7 & 30.5 & & 50.9 & 61.6 \\
Sweden & 27.6 & 39.4 & & 55.3 & 70.4 \\
Mexico & 6.4 & 14.8 & 71.6 & 48.1 \\
Thailand & 6.0 & 16.3 & 56.7 & 46.8 \\
\hline
\end{tabular}

Source: World Bank Projections, 1994 
for Mexico in the year 2030, and on the notion that Mexico is going through a similar aging process that other nations, only some decades behind. The assumption implies that we expect demographics to start playing against generational balance three decades from now. Second we assume that the rate of growth of population will be such that in the long term Mexico's population will be 200 million, almost twice than current population. ${ }^{8}$ Using this method, the average annual geometric growth rate of population for the period 2030-2100 would be 0.5 percent.

\subsection{The Age Distribution of Taxes and Transfers}

The next set of assumptions needed is about how each type of taxes and transfers is distributed across ages. The assumption that Auerbach, Gokhale and Kotlikoff (1991) made, and that has been adopted in all subsequent generational accounting applications, is that for every tax (transfer) the relative amount paid (received) by an average individual of a certain age is a constant multiple of the amount paid (received) by an average individual of a benchmark age. For example, if in 1997 an average 30 year old paid income taxes 0.8 times the income taxes paid by an average 40 year old (the benchmark), it is assumed that in all projected years an average 30 year old will pay income taxes 0.8 times the income taxes paid by a 40 years old. In generational accounts jargon, the set of multiples that describe the age distribution of a particular type of tax or transfer is called a "profile". We refer to each multiple in the profile as a "profile weight".

The profiles for each type of taxes and transfers need to be determined empirically. In this paper we obtained most of the profiles from the National Survey of Household Income and Expenditure (ENIGH), a periodic sample conducted by the Instituto Nacional de Estadística, Geografía e Informática (INEGI) - Mexico's official statis-

${ }^{8}$ This projection was made according to:

$$
\dot{P}_{t}=k P_{t}\left(\bar{M}-P_{t}\right)
$$

Where:

$P_{t:}$ Population in year $t$

$k$ : Constant

$M$ : Long term population tics authority. We use the information for household heads in the 1992 and 1994 surveys, which provide 23345 observations levied across all 32 Mexican states in both urban and rural communities. Table 2 indicates the profile assigned to each type of tax or transfer. For those taxes related to income we used the age distribution of income; ${ }^{9}$ for those related to consumption we used the age distribution of expenditure. Figure 2 shows the profiles for consumption and income. They are highly correlated and show very little evidence of life-cycle consumption smoothing, as predicted by the life-cycle/permanent-income hypothesis of Modigliani and Brumberg (1954) and Friedman (1957). ${ }^{10}$ The absence of life-cycle consumption smoothing — which leads to a concentration of consumption during the working age - increases the effect of a changing dependency ratio on the generational balance.

There are two types of transfers for which we used special profiles: health and pensions. For health we obtained the profile based on the distribution of health expenditure from the ENIGH. Here it should be mentioned that the correct profile to use should describe the age distribution of health expenditure made by the public sector, not by households. However, since we were unable to obtain the age distribution of public health spending, we use the private profile and address the problem in the sensitivity analysis section. We were also unable to obtain the actual pension payments age profile, so we use the U.S. profile for OASDI. ${ }^{11}$ Among the issues that further research should address is obtaining more adequate profiles for both health and pension payments.

\subsection{Public Finance Projections}

In order to calculate the various elements of the government's intertemporal budget constraint and the fiscal burden on current and future generations several projections are necessary. We classify such projections into six categories: $a$ ) taxes and transfers allocated to the

${ }^{9}$ Mexican public revenue data does not allow distinguishing personal income tax revenue from corporate income tax revenue. By using the same profile we assume that the incidence across ages is the same for both taxes. In a relatively small and open economy, such as Mexico, labor is likely to bear most of the burden of income taxation, making this a valid assumption. These arguments are explored in detail in Kotlikoff and Walliser (1995).

arguments are explored in detail in Kotlikoff and Walliser (1995).
Attanasio and Székely (1998) provides further evidence on the lack of life-cycle consumption smoothing in Mexico using the ENIGH.

1 The OASDI profile is the one used in J. Gokhale., B. R. Page and J. R. Sturrock (1998). 
Figura 2a. Female Profile

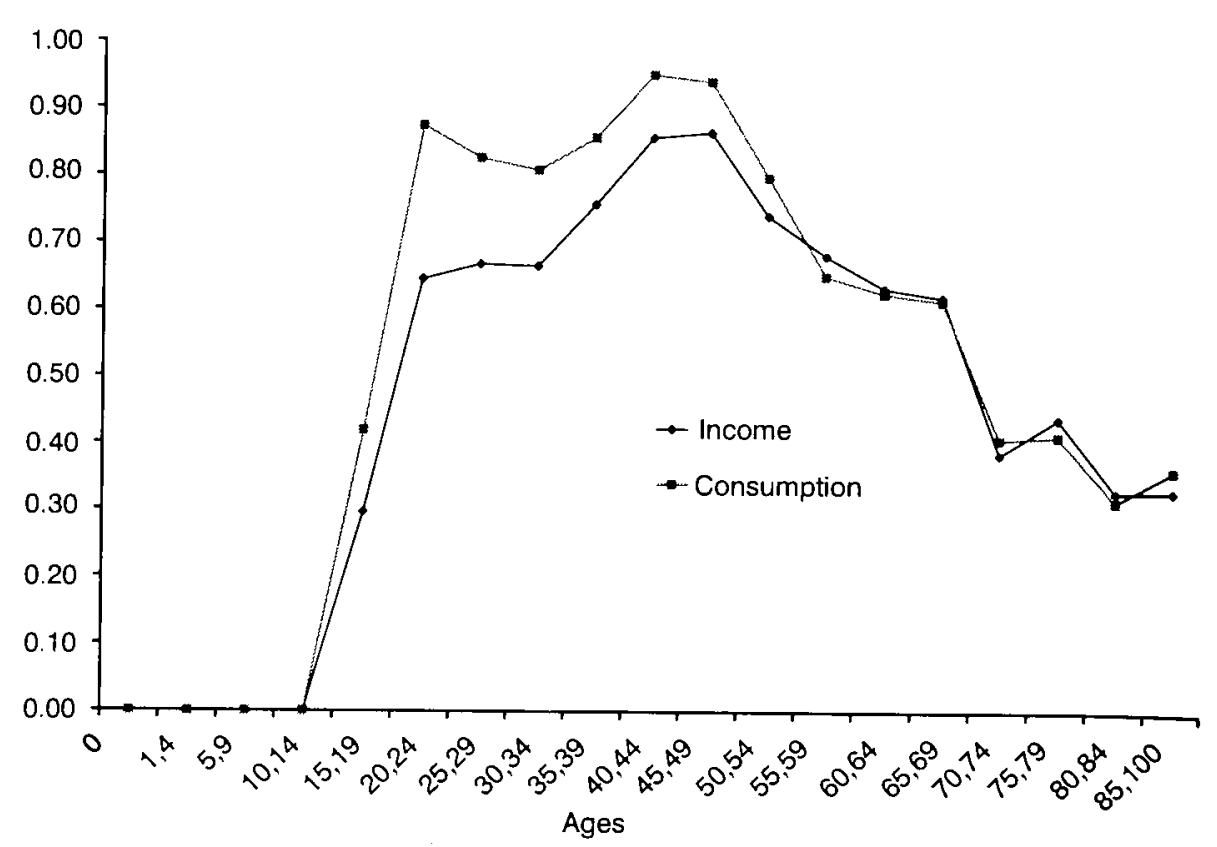

Figure 2b. Male Profile

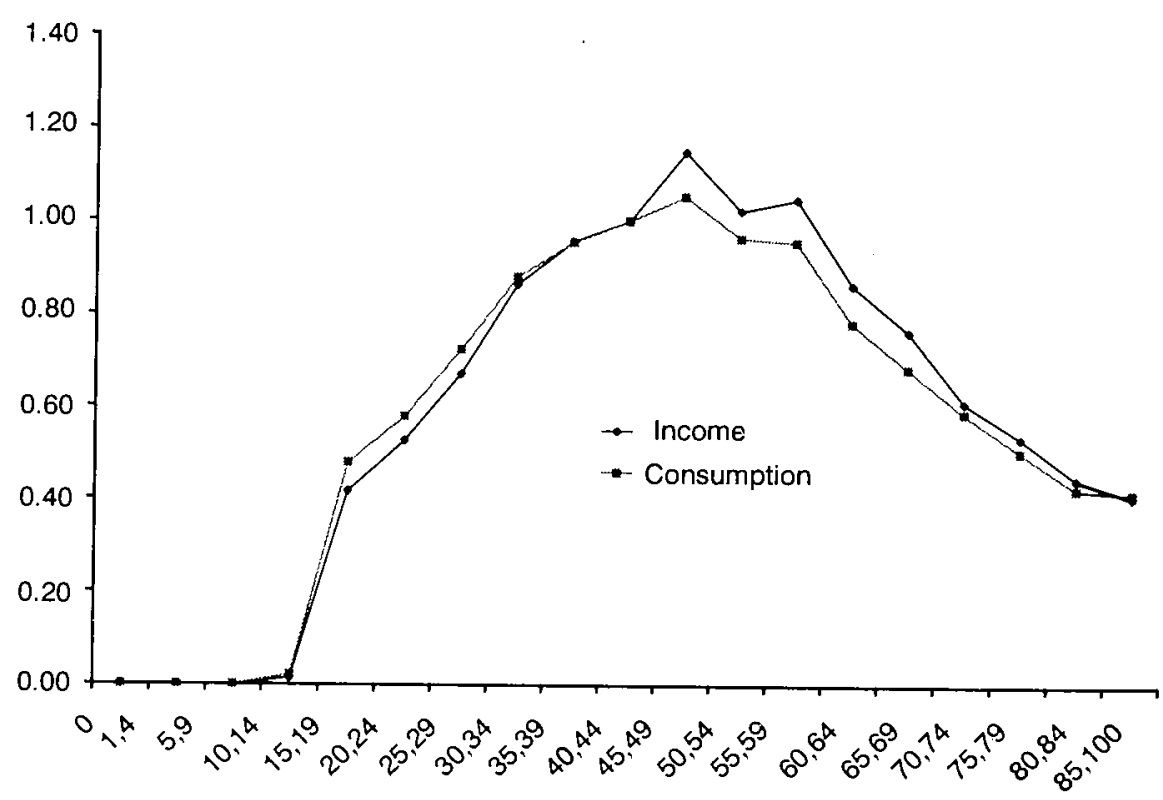

Ages

\section{Table 2}

\begin{tabular}{lll}
\hline \multicolumn{1}{c}{ Type } & \multicolumn{2}{c}{ Profile } \\
\hline Income tax & Income & ENIGH \\
Asset tax & Income & ENIGH \\
IMSS contributions & Income & ENIGH \\
ISSSTE contributions & Income & ENIGH \\
INFONAVIT contributions & Income & ENIGH \\
VAT & Consumption & ENIGH \\
Alcohol tax & Consumption & ENIGH \\
Beer tax & Consumption & ENIGH \\
Tobacco tax & Consumption & ENIGH \\
Vehicle property and new vehicle tax & Consumption & ENIGH \\
Foreign trade tax & Consumption & ENIGH \\
Seigniorage & Consumption & ENIGH \\
Healt public expenses & Health & ENIGH \\
Transition cost of pension system reform & OASDI & \\
Permanent cost of pension system reform & OASDI & \\
\hline
\end{tabular}

various cohorts through generational accounts, except public pensions of private sector workers and seignorage; $b$ ) public pensions of private sector workers; $c$ ) seigniorage; $d$ ) expenditure and revenue items not assigned by cohorts, except oil revenue; $e$ ) oil revenue; and $f$ ) the stock of net government debt. Table 3 shows the aggregate levels in base year 1997 for the main items in each category - expressed both in 1995 U.S. dollars and as percentage of GDP - and the source for each type. ${ }^{12}$ The choice of the base year is important for generational accounts. We chose 1997 mainly for two reasons. First, it is the most recent public finance data available. Second, and more important, tax revenues had not recovered to the pre- 1995 crisis levels, making our choice of base year a conservative one. The other two important variables for the base year decision are the price of oil and the level of public investment, which are subject to sensitivity analysis in another section of this paper. All projections are made in real terms.

12 All amounts are for 1997, except social security (IMSs) contributions, for which the growth-adjusted 1998 figure is used since pension reform was enacted only in the second half of 


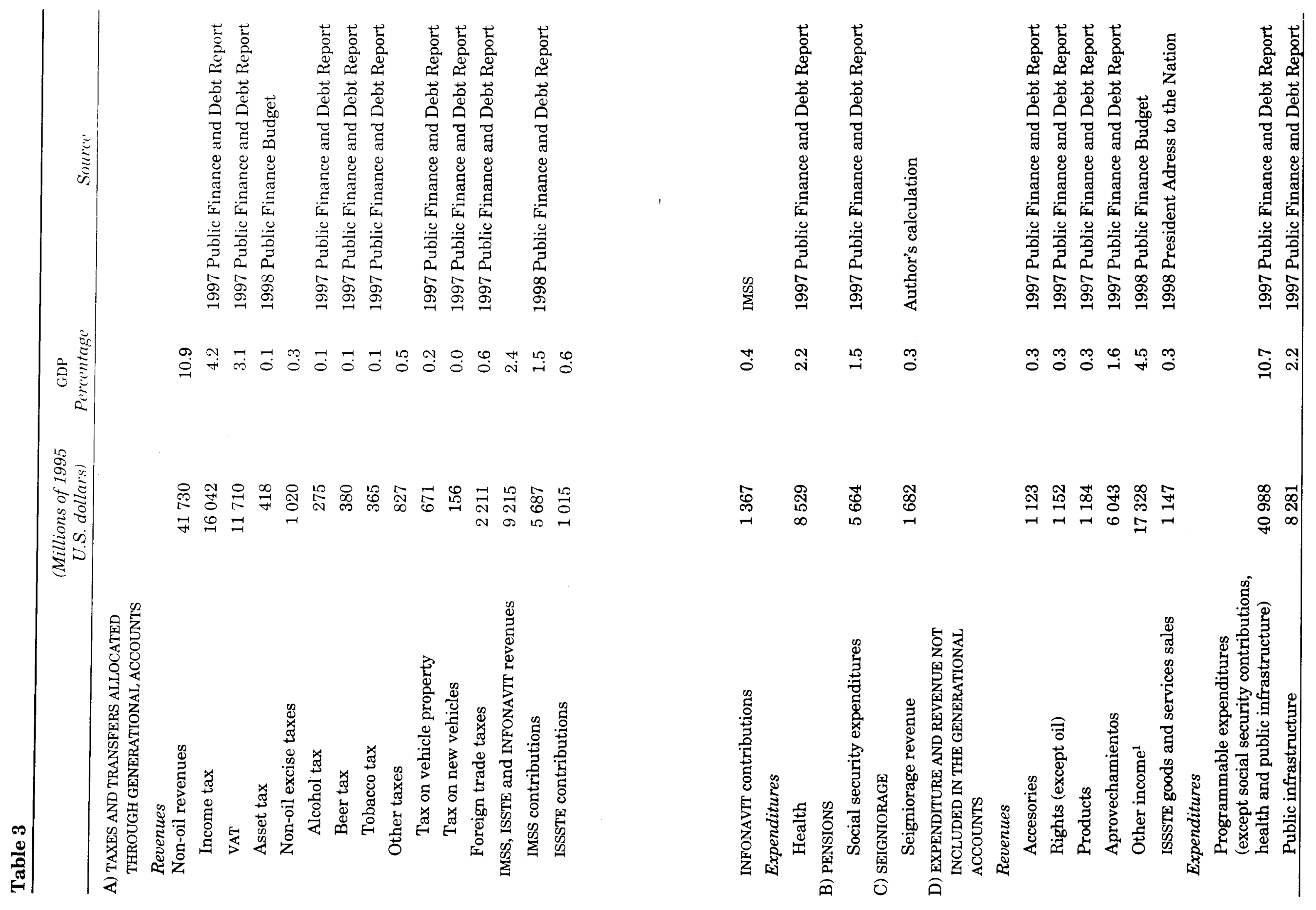




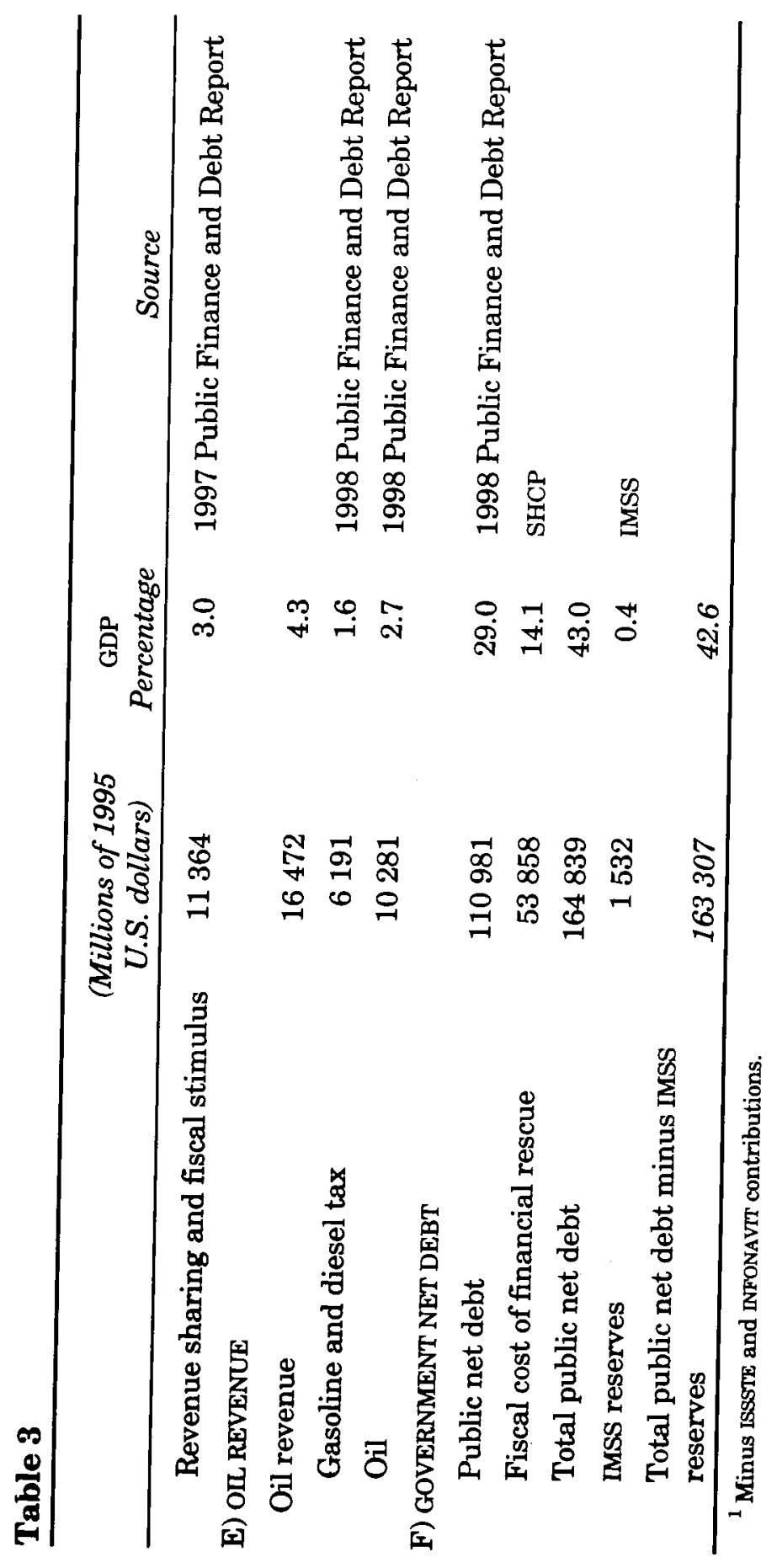

a) Taxes and transfers allocated to various cohorts through generational accounts. Given the population projections and the profiles, we project aggregate tax revenues and transfer payments that depend on the age distribution of the population and are included in the accounts of both current and future generations. This is done by assuming that the productivity of all workers will grow at a certain constant rate $g$ (which is discussed below) and applying the following formula:

$$
T_{t+i}=T_{t}^{40}(1+g)^{i} \sum_{j=1}^{J} W^{T, j} H_{t+i}^{j}
$$

where $T_{t+i}$ is the projected tax revenue (or transfer payments) of type $T$ in year $t+i, T_{t}^{40}$ is the tax payment of type $T$ by an average individual of the benchmark age 40 in the base year $t, W^{T, j}$ is the profile weight for tax (or transfer) of type $T$ for age $j, H_{t+i}^{j}$ is population of age $j$ in year $t+i$ and $J$ is the maximum age. Therefore, aggregate tax revenue and transfers payments are projected starting from their observed levels in base year 1997 depending on how population and productivity are expected to evolve.

b) Pensions. In 1997 the Mexican pension system for private sector workers went through a major overhaul, substituting the existing pay-as-you-go defined-benefit scheme with a fully-funded definedcontribution scheme. The transition cost of the reform will take place over the next 51 years. We used the estimates of yearly transition and permanent pension costs presented in Sales, Solís and Villagómez (1996), where a detailed description of the reform may also be found.

c) Seigniorage. The revenue obtained by the central bank derived from the real increment in the monetary base has been on many occasions an important component of public sector revenue in Mexico. Between 1990 and 1998 it averaged 0.5 percent of GDP. In order to calculate future seigniorage we project the growth rate of the monetary base to be equal to the growth rate of nominal GDP. ${ }^{13}$ To obtain the latter we assume annual inflation will average 10 percent over the projection span, which would be significantly lower than the average

${ }^{13}$ This approach ignores the benefits to the central bank of an outward shift of the demand for money caused by decreasing inflation expectations, as well as any transactions technology shift that may diminish the demand for monetary base in the future. 
inflation rate of 35.4 percent over the last three decades (we present sensitivity analysis to this assumption in the results section). The profile used for seigniorage is the ENIGH consumption profile.

d) Expenditure and revenue not included in the accounts. Excluding transfers listed in Table 2 , government expenditures - such as infrastructure and security - are projected to remain constant as a share of GDP. This is also the case of those revenue items that are not included in Table 2. Combining the population and productivity growth rates we obtain GDP projections. Since population growth is expected to slowdown, GDP growth is projected to diminish from 3.0 percent in 2000 to 2.1 percent by 2030 . It should be noted that expenditure items not assigned into the accounts include outlays related to education. Recent applications of generational accounting have included education expenditures in generational accounts. We were unable to do that due to data unavailability. Assigning educational expenditure into the accounts would favor generational balance in Mexico, since the number of individuals (mostly young) receiving the benefits of public education is expected to decrease as a share of working individuals. Therefore, in this respect, our analysis is biased against generational balance.

e) Oil revenue. Oil is a major component of government financing in Mexico. Over the last ten years oil revenue has accounted on average for 31.7 percent of total government revenue and it will likely continue to play a major role. In essence, oil in the ground is a government asset of uncertain value. Therefore, in order to include oil revenue in the government's budget constraint the value of oil reserves has to be estimated. The value of oil reserves depends basically on four variables, all of them difficult to predict: the amount of reserves, the cost of extraction, the extraction path and the behavior of the price of oil in the future. ${ }^{14}$ In this paper we do not attempt to forecast these variables. Our strategy has been to assume that oil revenue will be equal to the one observed in 1998 until reserves run out. By assuming that actual reserves equal 1.5 times present proven reserves, we estimate that oil revenues will last 72 years. We perform sensitivity analysis to alternative sizes of reserves. ${ }^{15}$

\footnotetext{
${ }^{14}$ The extraction path becomes an endogenous value if it is set as to maximize the value of reserves.

${ }^{15}$ Proven reserves typically do not reflect the full amount of reserves, as they only refer to those sufficiently studied and that would be economically viable to extract if current techno-
} logical and market conditions prevailed.
To base our forecasts of oil revenue on the one observed in 1998 means that we are adopting a conservative strategy for three reasons. First, 1998 prices in real terms were the lowest since the oil embargo of 1973; second, extraction costs are likely to decrease, as it has been the case over the past three decades; and third, the extraction path may be optimized, in particular by increasing the extraction rate These three factors imply that we are probably underestimating the value of oil assets and therefore again biasing our results against generational balance and fiscal sustainability.

f) Government net debt. Government debt is composed by internal and external debt issued by the treasury and the major state companies, and by the liabilities generated by the financial rescue of the banking system and the private highway program. We use a total indebtedness figure of 42.6 percent of GDP (U.S. \$ 163307 million of 1995), of which 14.1 percent of GDP corresponds to the bank and highway bailout cost.

\subsection{Productivity Growth and Discount Rates}

Given the long-term nature of the generational accounts analysis, it is not surprising that the choice of productivity growth and discount rates has a significant impact on the results. The choice of the correct rates, however, is not trivial. Our approach has been to use the same rates that have been used in the majority of the previous generational accounting applications to other countries, in order to facilitate comparisons. As in other studies, we perform sensitivity analysis to both rates. In our base case the rate of labor productivity growth is set to 1.5 percent a year, and the discount rate to 5 percent. These values are within the range of what has been observed in Mexico. Over the last three decades the average rate of growth of labor productivity has been 1.6 percent; ${ }^{16}$ and over the $1985-1998$ period the average real interest rate has been 4.7 percent. ${ }^{17}$

\footnotetext{
${ }_{17}^{16}$ Authors' calculation.

${ }^{17}$ Based on 28 days government bonds (CETES) and the consumer price index
} 


\section{Results}

In this section we present our base case results and several analyses of their sensitivity to our main assumptions. The results were obtained by running the original generational accounts software with the data discussed in section II as input. ${ }^{18}$ By using the same computer code, our results are comparable to those of other studies. All figures are shown in 1995 U.S. dollars.

\subsection{Base Case Results}

Tables $4 \mathrm{a}$ and $4 \mathrm{~b}$ present our base case estimates for men and women. The first column in each table presents the generational account for generations age 0 to 80 grouped in five-year intervals in 1997. The first row shows the account for newborns, which is $\$ 7.4$ thousand dollars for men and $\$ 7.0$ thousand dollars for women. This means that a male born in 1997 would expect to pay in present value net taxes of $\$ 7.4$ thousand dollars over his life-time. The generational accounts then get larger for older generations, peaking at age 30 . After age 30 the accounts decrease and turn negative by age 60 for men and 55 for women. This U-shaped pattern is found in most generational accounts for other countries, and is consistent with the notion that the present value of net tax payments is highest at the early stages of the working age. In contrast, individuals in the late stages of life are expected to face negative net taxes, derived from the importance of pension payments and health benefits received by the elderly. The rest of the columns in the tables show the components of the accounts for each living generation.

Tables $4 \mathrm{a}$ and $4 \mathrm{~b}$ also show the generational accounts for men and women of future generations, $\$ 6.6$ thousand and $\$ 6.2$ thousand respectively. By comparing the size of these accounts against those of newborn men and women we observe that the accounts of future generations are smaller by approximately 11 percent. This means that, in our base case, we find no evidence of a fiscal sustainability problem. Instead we detect a "negative imbalance", that means there

${ }^{18}$ The code was generously provided by L. J. Kotlikoff, A. Auberbach and P. Oreopoulos and is the version used for the paper J. Gokhale., B. R. Page and J. R. Sturrock (1998). would be potential room to cut lifetime taxes of the living and still not increase the burden on future generations.

Table 5 compares our base case results with the findings for other 17 countries reported in Kotlikoff and Liebfritz (1998), all calculated with the same discount and productivity growth rates ${ }^{19}$ as in our base case. We scaled the figures in order to remove the differences arising from different current levels of GDP per capita. The table therefore shows the accounts that the 18 countries would have if all shared the same GDP per capita as the U.S. in 1997. Along with Mexico, only Canada, New Zealand, Sweden and Thailand show no evidence of a problem of fiscal sustainability. On the opposite side of the spectrum, Japan, Italy and Germany show very high imbalances that imply that if policies are not adjusted the burden of future generations will be twice or more the burden of newborns. The other two Latin-American countries in the table, Argentina and Brazil, also show imbalances of more than 50 percent.

Table 5 also permits to compare across nations the lifetime fiscal burden that a newborn would face if current policies remained unchanged. It is interesting to note that there is no correlation between the size of the burden on current generation (adjusted by current GDP per capita) and the size and sign of the imbalance. The size of the burden is largest in Sweden, where there is no problem of fiscal sustainability. However, Germany has a large burden and a large sustainability problem, while Thailand and Mexico have relatively small tax loads and present no imbalance. This fact shows that the level of net taxation by itself is not an adequate indicator of fiscal soundness and that comparing tax rates across countries has little relevance in the assessment of fiscal sustainability.

The main reason why we do not detect a fiscal sustainability problem in Mexico is the very favorable demographic transition that Mexico will undergo over the next three decades. As we explained in the previous section, the total dependency ratio will fall from 71.6 percent in 1990 to 48.1 percent in by the year 2030 , playing in favor of generational balance. In Table 6 we illustrate the importance of the demographic factor by showing the imbalance that would exist if the population remained unchanged throughout the projection span. If no demographic transition occurred, current fiscal policies would

${ }^{19}$ The accounts shown in Table 5 correspond to Case A of Kotlikoff and Liebfritz (1998), in which educational expenses are not included in the accounts. 




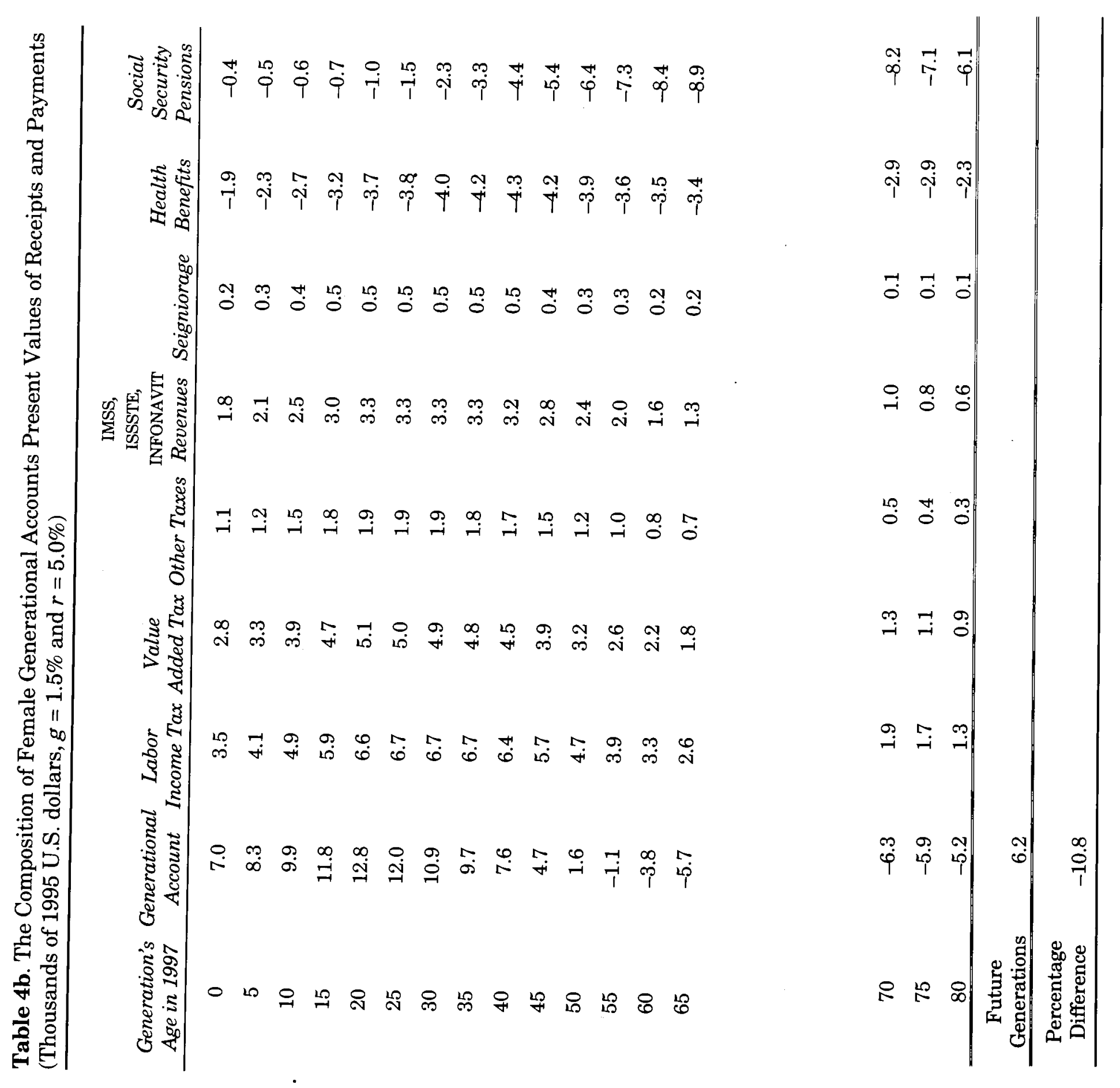




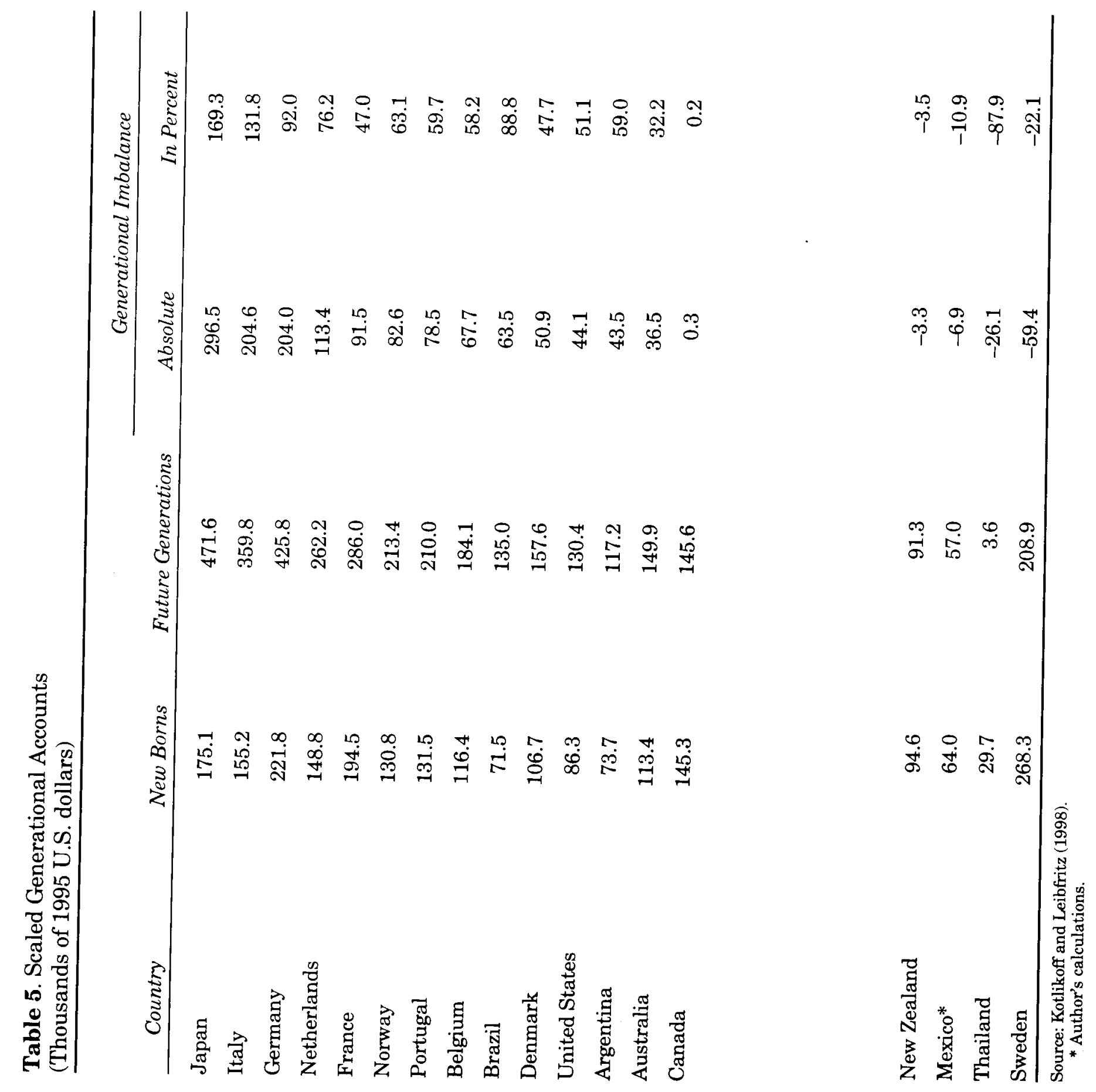


Table 6. Imbalance Sources

$(g=1.5 \%, r=5 \%)$

\begin{tabular}{lcccc}
$\begin{array}{c}\text { (Thousands of 1995 } \\
\text { U.S. Dollars) }\end{array}$ & $\begin{array}{c}\text { Newborn } \\
\text { Generation }\end{array}$ & $\begin{array}{c}\text { Future } \\
\text { Generation }\end{array}$ & $\begin{array}{c}\text { Absolute } \\
\text { Imbalance }\end{array}$ & $\begin{array}{c}\text { Relative } \\
\text { Imbalance }\end{array}$ \\
\hline & & & & \\
Base Case Scenario & 7.4 & 6.6 & -0.8 & $-10.9 \%$ \\
No Demographic Change & 4.4 & 10.1 & 5.8 & $132.0 \%$ \\
No Oil Revenues & 7.4 & 13.1 & 5.7 & $76.8 \%$ \\
\hline
\end{tabular}

result in a major fiscal sustainability problem, that would force future generations to pay 132 percent more lifetime net taxes than current generations are expected to pay. This exercise makes the point that the absence of a fiscal sustainability problem in Mexico is due mostly to very favorable population dynamics, not current fiscal policies.

Table 6 also shows the importance that oil has in explaining the benign result. If oil revenues were excluded, an imbalance of 77 percent would arise. An important implication is that, even if we assume that low oil prices will prevail in the long run (as we have done), oil reserves are a very valuable fiscal asset. Therefore, the debate over the dependency of fiscal revenue on oil should not be about diminishing the amount of oil revenue, but instead about maximizing the value of the reserves and about mitigating the negative effects of oil price volatility.

\subsection{Sensitivity Analysis}

The findings from our base case are subject to several assumptions we made in order to project the variables needed to carry out the generational accounting exercise. The first issue to check is the importance of the productivity growth rate and the discount rate. We recalculated the accounts with productivity growth rates of 1 percent, 1.5 percent and 2 percent and discount rates of 3 percent, 5 percent and 7 percent. These ranges are the same used in the 17 countries studies described in Kotlikoff and Liebfritz (1998). Table 7 shows the nine scenarios that result from combining these values.




The first fact to notice is that, for a given discount rate, an increase in the rate of productivity increases the sizes of the accounts for both newborns and future generations. This is because as income rises, so does the amount of government expenditure and taxes paid. Second, an increase in productivity growth plays against generational balance. We attribute this result - which seems counterintuitive to the presence of sizeable oil wealth in the government's budget constraint. Since the level of oil revenues is independent of the size of income, an increase in public expenditure (resulting from increased income) has to be financed by non-oil revenue. This in turn increases the share of non-oil revenues to GDP; since the share of lifetime taxes to lifetime income of living generations is projected to remain essentially constant, the excess burden is placed on future generations. Because oil assets are larger in value than the public debt, ${ }^{20}$ this effect dominates the reduction of debt service as a share of GDP when productivity rises.

Table 7 also shows the effect of changing the discount rate. A higher discount rate decreases the size of the accounts for both newborns and future generations, since the flows of net taxes paid in the future are discounted more heavily. However, using a lower discount rate ( 3 percent), turns the negative balance into positive. We explain this by noting that a lower discount rate gives a larger weight to the years after 2030 , when we project demographics to play against generational balance, as Mexico will enter the later stages of the aging population process. However, a 3 percent discount rate appears unrealistically low for a developing economy such as Mexico.

Table 8 summarizes the outcome of several exercises that test the robustness of our base case results to changes in some of the assumptions we have made. The exercises performed are related to: $a$ ) the health transfers profile; $b$ ) the epidemiological transition; $c$ ) government liabilities arising from the public sector workers pension system (ISSSTE); $d$ ) the banking system rescue; $e$ ) infrastructure investment by the government.

a) Health transfers profile. We mentioned in the previous section that, due to limits in data availability, we used the ENIGH profile of private health spending to distribute public health expenditure across ages. If the age distribution of health transfers is different to the age

20 The present value of oil revenues (using the 5 percent discount rate) is $\$ 341559$ million of 1995 dollars, while net debt is $\$ 163307$ million of 1995 dollars. distribution of private health outlays, our results may be incorrect. Since public and private expenditure may substitute each other, their age distribution may be different. In particular, elderly individuals may consume more publicly provided health services since their income is lower and their medical services needs are higher. A way to address this concern is to recalculate the generational accounts using a health transfers profile that gives more weight to elderly individuals. We did such exercise using the U.S. Medicaid profile, ${ }^{21}$ and found a generational imbalance of 15 percent. However, this result is an extreme since Medicaid is targeted only to the elderly, while the Mexican government provides health services for all ages. The correct profile is probably at some middle point that would leave the accounts within a narrow range of balance.

b) The epidemiological transition. The demographic transition is likely to have a negative effect on the adequacy of public health infrastructure. As the population ages the pattern of medical services demanded will shift a phenomenon known as epidemiological transition. The shift in needs will generate an excess supply of medical infrastructure adequate to serve the young and insufficient medical infrastructure apt to serve the old. The epidemiological transition implies, therefore, that public medical capital depreciation will acuderate. If this is the case, the government will face a burden not considered in our base case. Since we do not have enough elements to estimate the cost of the epidemiological transition, we incorporated its cost by increasing the annual growth rate of health expenditures over the next 30 years by an arbitrary 0.5 percent. This results in a relatively small generational imbalance of 4 percent.

c) ISSSTE pension liabilities. As opposed to the pensions system for private sector workers (provided by the IMSs), the pay-as-you-go pension system of public sector workers provided by the ISSSTE has not been reformed. Preliminary estimates indicate that the implicit liability for the government arising from non-funded ISSSTE pensions can be as high as 12 percent of GDP. ${ }^{22}$ We added this amount to the net debt of the public sector and obtained a small generational imbalance of 2 percent.

d) The banking system rescue. After the economic crisis that Mexico went through in 1995 the government assumed significant

21 J. Gokhale, B. R. Page and J. R. Sturrock (1998)

${ }^{22}$ Centro de Análisis e Investigación Económica, ITAM (1998). 
liabilities from a large portion of the banking system. The official estimate of the present value cost of the rescue program to be paid in the future is $\mathbf{1 4 . 1}$ percent of GDP. This figure, however, may underestimate the cost of the bank bailout, in particular because many banks continue to be weak and they could require further public funding. To address this issue we recalculated our base case assuming a total liability of 28.2 percent, twice the official estimate. Under this assumption we obtain a small generational imbalance of 4 percent.

e) Infrastructure spending. In 1997 infrastructure spending by the public sector was 2.1 percent of GDP, a low figure by historical standards. A low level of infrastructure spending can lead to an infrastructure deficit that may eventually trigger higher spending. We recalculated our base case with annual government outlays for infrastructure equivalent to 2.5 percent for GDP-higher than observed average of 2.3 percent in the period 1990-1998. Under this assumption our main result is reversed, as we find a generational imbalance of 8 percent.

Table 8 also presents a scenario in which three of our alternative assumptions are combined: the epidemiological transition, the ISSSTE liabilities and the additional infrastructure spending. The outcome, a 38 percent generational imbalance, is a relevant reversal of our base case result. We interpret this finding as a reminder that although demographics will favor generational balance, there are structural elements in Mexican public finances that - combined - have the potential of making current fiscal policies unsustainable. However, this conclusion should be weighted against the fact that, by not including educational outlays in the accounts and by using a historically low price of oil, we bias our results against generational balance.

\section{Long-run Balance vs. Short-run Financing}

Our results indicate that there is no evidence of a major intergenerational imbalance in Mexico, comparable to those existing in many developed countries, and that this conclusion is mainly driven by favorable demographics. However, this analysis may not be enough to determine if the current fiscal policies are sustainable in the short-run. In this section we analyze the short-run financing needs of the government which, if too high, could make the whole path unfeasible.

The government can run substantial deficits and still comply with

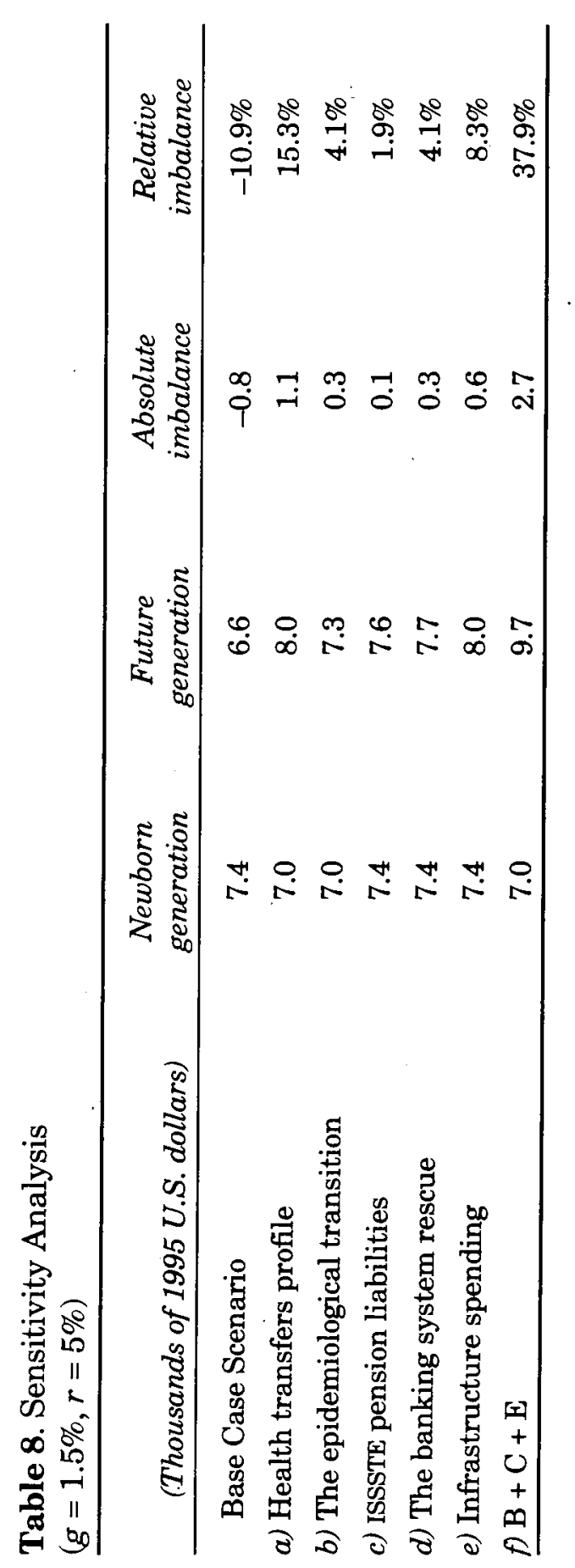


Figure 3. Projected Primary Balance (\% of GDP)



its intertemporal budget constraint, if in the future it receives net positive flows. However, under imperfect capital markets this may not be viable, as creditors may refuse to lend funds to a government running large deficits. This would force the government to adjust its policy course. Therefore, beyond evaluating the intergenerational balance, the full assessment of fiscal sustainability may need to look at the expected path of the government deficit.

Figure 3 shows the average projected primary government balance for 10-year periods up to 2070 under our base case. The primary balance is equal to all government revenues minus government expenditures except those related to interest payments on its debt. ${ }^{23}$ It can be observed that for all years, the projections show primary surplus. It declines until the decade of 2030 and thereafter, once the transition cost of the pensions reform is paid, the surplus rises. Although the existence of a primary surplus is not enough to avoid a short-run problem, its permanence is an indicator that short-run financing may not prevent fiscal sustainability.

23 The financing of the pension system reform is not substracted from government expenditures in order to calculate the primary balance.

\section{Concluding Remarks}

Generational accounts are a powerful tool for evaluating fiscal policy. They are useful to assess the intergenerational distribution of fiscal burdens and to provide an indication of long-term fiscal policy sustainability. In this paper we presented the first application of generational accounts methodology to evaluate overall Mexican fiscal policy.

Our results are significantly driven by the favorable demographic transition that the Mexican economy will undergo during the next three decades. In that period, the labor force will grow at an average yearly rate of 1.4 percent while the rate of population growth will be 1.0 percent and the total dependency ratio will diminish from 71.6 percent in 1990 to 48.1 percent in 2030. Mainly because of the demographic transition, we find no evidence of a fiscal sustainability problem. Our base-case scenario with annual productivity growth of 1.5 percent and a discount rate of 5 percent shows that the present value of net tax payments for future generations is 11 percent lower than those for newborns. Since we do not allocate education expenditure in the accounts, our analysis is already biased against finding generational balance. The results are sensitive to the rate of growth of productivity and to the discount rate, and to several alternative data assumptions. However, the main conclusion - that there is no intergenerational imbalance of the sort found for other countries - is sustained under most scenarios.

This result speaks about the long-term sustainability of current fiscal policy. However, it is also important to analyze the evolution over time of the fiscal deficit. Since financial markets are imperfect, a high fiscal deficit in the near future that could be covered by surpluses in the longer term could have negative implications on the growth rate of the economy. However, when we analyzed the evolution over time of public finances, we did not find evidence of large fiscal deficits in the future. Needless to say, this result obviously assumes no major negative fiscal shocks in the next years.

Although our analysis only presents a first approach towards a deep understanding of the long-term sustainability of Mexican fiscal policy, some preliminary policy implications can be obtained. The three most important are the following:

1) There is no need to increase the overall level of taxation in the Mexican economy. The main focus of tax policy reform should be 
microeconomic. Tax changes should be aimed at achieving a more efficient tax structure. Some analysts have pointed out that the overall level of taxation in Mexico is relatively low compared to other countries and suggest this as a reason to increase taxes. This paper shows that this comparison is not relevant. The level of taxation should be that which enables the government to comply with its intertemporal budget constraint once society has decided the types and level of expenditures that the government should carry out. Our analysis shows no clear evidence that the current expected level of taxation is inconsistent with the expected path of government outlays.

2) Oil is a valuable natural resource that should be used to support public finances in Mexico. It provides a significant source of revenue for the government and there is no reason why it should not continue to do so. Our analysis shows that even under sustained low oil prices, oil is a key factor explaining fiscal sustainability. The main problem emerges from the instability of the flow of oil revenues, mainly derived from oil price volatility. The challenge is to establish mechanisms that would reduce this variability. Schemes such as hedging, creation of an oil fund, accessing private markets and others should be studied and implemented.

3) Mexico will face a window of opportunity to carry out structural reforms that imply inter-generational transfers. The demographic transition implies that over the next three decades, Mexicans in working ages as percentage of total population will reach a peak. This provides an opportunity to widely distribute the costs of any structural reform that implies a transition cost. After the reform of private sector pensions which was timely enacted in 1997, other important sectors that need to be reformed include health, housing and public sector workers' pensions. These reforms should be designed and implemented as soon as possible.

The agenda for future research regarding the long-term implications of Mexican fiscal policy using generational accounts is large: It can be divided into two areas. The first one would be to refine data, assumptions and calculations regarding the assessment of current fiscal policy. Perhaps the main focus should be on demographics, the age distribution of health transfers and pensions benefits, the allocation of educational outlays in the accounts, the liabilities arising from the public sector workers' pension system and the epidemiological transition in Mexico. A second area would be to carry out policy reform simulations. Generational accounts can be useful to evaluate the generational impact of important reforms in Mexico related to taxation, pensions, health and housing, among others.

\section{References}

Attanasio, O., and Miguel Székely (1998), "Household Savings and Income Distribution in Mexico", in this volume.

Auerbach, A. J., J. Gokhale, and L. J. Kotlikoff(1991), "Generational Accounts: A Meaningful Alternative to Deficit Accounting", in D. Bradford (ed.), Tax Policy and the Economy, 5, Cambridge/Mass., pp. 55-110.

(1992), "Generational Accounting: A New Approach to Understanding the Effects of Fiscal Policy on Saving", Scandinavian Journal of Economics, 94, pp. 303-318.

(1994), "Generational Accounting: A Meaningful Way to Evaluate Fiscal Policy", Journal of Economic Perspectives, 8, pp. 73-94.

Auerbach, A., J., L. J. Kotlikoff, and W. Leibfritz (eds.) (forthcoming 1999), Generational Accounting Around the World, NBER.

Centro de Análisis e Investigación Económica (1998), “Análisis de la coyuntura económica”.

Friedman, Milton (1957), A Theory of the Consumption Function, Princeton University Press.

Gokhale J. , B. R. Page, and J. R. Sturrock (1998), “Generational Accounts for the United States: An Update", mimeo.

Kotlikoff, L. J., and J. Walliser (1995), “Applying Generational Accounting to Developing Countries", mimeo.

Kotlikoff, Laurence J., and W. Leibfritz (1998), "An International Comparison of Generational Accounts", NBER 6447.

Modigliani, Franco, and Richard Brumberg (1954), "Utility Analysis and the Consumption Function: An Interpretation of Cross-section Data", in Kenneth K. Kurihara (ed.), Post-Keynesian Economics, 388-436, New Brunswick, N. J., Rutgers University Press.

Secretaría de Hacienda y Crédito Público (fourth quarter, 1997), Public Finance and Debt Report.

Serrano, Carlos (1998), "Social Security Reform, How Much will It Cost and Who will Pay for It: The Mexican Case", University of California at Berkeley, mimeo.

Solís, S., F. Alejandro Villagómez, and Carlos Sales (1996), "Pension System Reform: The Mexican Case", NBER 5780. 